\title{
IRRIGATION SCHEDULING TO INCREASE WATER UNIT PRODUCTIVITY OF WHEAT-MAIZE ROTATION UNDER CLIMATE CHANGE CONDITIONS
}

\author{
Foad. A. Khalil ${ }^{1 *}$, Samiha A. Ouda ${ }^{1}$ and Gamal El Afandi ${ }^{2}$ \\ ${ }^{1}$ Water Requirements and Field Irrigation Research Department; Soil, Water, \\ and Environment Research Institute; Agricultural Research Center; Egypt. \\ ${ }^{2}$ Metrology and Astronomy Department; Collage of Science, Al Azhar \\ University, Egypt.
}

\begin{abstract}
Irrigation scheduling according to comulated pan evaporation was used to increase water unit productivity of wheat (Triticum aestivum L.) and maize (Zea mays L.) rotation under two climate change scenarios. Three wheat varieties and two maize hybrids were planted in 2-yr field experiments. CropSyst model was calibrated and validated for the collected field data, then was used to assess the impact of two climate change scenarios (A2 and B2) and three adaptation strategies (early sowing changing, irrigation schedule and the interaction between them) in the year of 2038s. The results revealed that A2 reduced yield more than B2 scenario for both crops. High yield reduction in wheatmaize rotation could be expected under climate change conditions, where wheat and maize yield will be reduced by an average of 41 and $56 \%$, respectively. The most effective adaptation strategy for wheat was sowing 3 wk earlier and irrigation every $21 \mathrm{~d}$, with irrigation water saving and no yield improvement under A2 scenario in both growing seasons. Whereas under B2 scenario yield improvement by $2 \%$ occurred with $3 \%$ saving in the applied irrigation water in the $1^{\text {st }}$

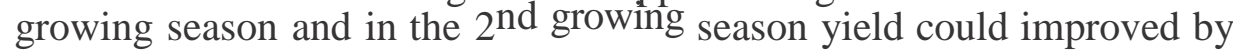
$8 \%$ with less than $1 \%$ increase in the applied irrigation water and higher water productivity. Changing irrigation schedule was an effective adaptation option for maize, where yield improvement could occur under both climate change scenarios in both growing seasons by up to 9\% with less than $3 \%$ increase in the applied irrigation water and higher water productivity.
\end{abstract}

Key words: Pan evaporation technique, CropSyst, HadCM3, climate change scenarios, adaptation strategies.

\section{INTRODUCTION}

Irrigation scheduling is a technique to timely and accurately give water to a crop. Jensen (1980) referred to irrigation scheduling as "a planning and decision-making activity that the farm manager or operator of an irrigated farm is involved in before and during most of the growing season". Irrigation scheduling has been described as the primary tool to improve water use efficiency, increase crop yield, increase the availability of water resources, and provoke a positive effect on the quality of soil and groundwater (FAO, 1996). The technique of using pan evaporation in irrigation scheduling has been extensively tested by many researchers in Egypt (Khalil, 1996; Ashraf et al., 2002; Khalil et al., 2006) and it was proven to save about of $20 \%$ from the applied irrigation water by farmers. Therefore, under Egyptian conditions, extension agricultural personal are recommending scheduling irrigation using pan evaporation technique to the farmers as a way to conserve

Fayoum J. Agric. Res. \& Dev., Vol. 26, No.2, July, 2012 
irrigation water.

Crop water productivity is a quantitative term used to define the relationship between crop produced and the amount of water involved in that crop production. It is a useful indicator for quantifying the impact of irrigation scheduling decisions with regard to water management (FAO, 2003). Future climate change could have the potential to significantly alter the conditions for crop production with important implications for worldwide food security (Rosenzweig and Hillel, 1998). Changes in yield behavior in relation to shifts in climate can become critical for the economy of farmers. An increasing probability of low returns as a consequence of more frequent occurrence of adverse conditions could prove dramatic for farmers operating at the limit of economic stress (Torriani et al. 2007b).

Therefore, climate change urgently needs to be assessed at the farm level, so that poor and vulnerable farmers dependent on agriculture can be appropriately targeted in research and development activities o $n$ poverty alleviation (Jones and Thornton, 2003). Assessing the possible impact of climate change on production risks is therefore necessary to help decision makers and stakeholders identify and implement suitable measures of adaptation (Torriani et al., 2007b). Wheat-maize rotation is a favorite one by the Egyptian farmers due to its high profitability in Middle Egypt. Under climate change conditions, both wheat and maize production could be adversely affected by heat stress resulting from climate change condition. Regarding to wheat, numbers of tillers are usually decreased when wheat plants were exposed to high temperature (Friend, 1965). Furthermore, high temperature during anthesis causes pollen sterility (Saini and Aspinall, 1982) and reduces number of kernels per head, if it prevailed during early spike development (Kolderup, 1979). The duration of grain filling period could be reduced under high temperature (Sofield et al., 1977), as well as growth rates with a net effect of lower final kernel weight (Bagga and Rawson, 1977; McMaster, 1997). Similarly, heat stress could accelerate the rate of maize plant growth (Ritchie $\boldsymbol{e t}$ al., 1993) and consequently reduce growing season length. High temperature can reduce kernel sink capacity and limit subsequent kernel development and final maize yield (Cheikh and Jones, 1994). It has been suggested that each $1^{\circ} \mathrm{C}$ increase in temperature above optimum could result in a reduction of 3 to $4 \%$ in grain yield (Shaw, 1983). During the early stage of kernel development, heat stress is particularly detrimental to subsequent dry matter accumulation, because it disrupts cell division, sugar metabolism, and starch biosynthesis in the endosperm (Monjardino et al., 2005). Thus, it is expected that climate change will have implications for possible fluctuation on wheat yield (Wrigley, 2006) and maize yield (Díaz-Ambrona et al., 2004). Previous research in Egypt predicted reduction in the national wheat production by up to $30 \%$ and increase in its water needs by up to $3 \%$ (Eid et al., 1992; 1993; 1994) by 2050. Furthermore, national maize production will decrease by $25 \%$ in 2050 as it was projected using GCMs or MAGICSENGEN scenarios (Eid et al., 1992; 1997; Eid and El-Mowelhi, 1998).

Using process-based models of crop growth, such as CropSyst (Stockle $\boldsymbol{e t}$ al., 1994) along with a set of daily weather data spanning a reasonable number of years could be a suitable solution to assess the impact of climate change on agriculture (Tubiello et al., 2000; Torriani et al., 2007a). The application of such models allows the simulation of many possible climate change scenarios from only a few experiments for calibration. Furthermore, the effect of using different adaptation strategies on the yield of the simulated

Fayoum J. Agric. Res. \& Dev., Vol. 26, No.2, July, 2012 
crops could also be assessed to determine its efficacy in improving yield under climate change conditions. The objectives of this research were (i) to use CropSyst model to assess the impact of two climate change scenarios on the yield and consumptive water use of wheat and maize crops; (ii) to use the model to determine the efficiency of the proposed adaptation strategies in improving the yield and water productivity of the two crops under climate change scenarios.

\section{MATERIALS AND METHODS}

Field experiments:

Two-year field experiments for wheat and maize were conducted at Giza Agricultural Research Station (31 $13^{\prime} \mathrm{S}, 30^{\circ} 02^{\prime} \mathrm{E}, 22.5$ m.a.s.1.), middle Egypt. Wheat (as winter crop) was planted in 2007/2008 and 2008/2009 growing seasons and maize (as summer crop) was planted in 2008 and 2009 growing seasons. The surface methal irrigation was used and irrigation was applied at 1.2 comulative pan evaporation which is the optimum irrigation treatment for wheat and maize under Giza climatic conditions. Evaporation data were collected daily from a standard Class-A-Pan located near the experimental field. Irrigation amounts were calculated for both crops according to the following equation (Allen et al., 1998):

$\mathrm{I}=$ Epan. Kpan

where $I$ is reference evapotranspiranspiration $(\mathrm{mm})$, Epan is the evaporation in the period of irrigation interval $(\mathrm{mm}), K p$ is the pan coefficient. Actual evapotranspiration for both crops was estimated by the soil sampling method and calculated between each two successive irrigations according to the following formula: Israelsen and Hansen, (1962).

$\mathrm{CU}=(\theta 2-\theta 1) \mathrm{Bd}$ ERZ

Where $C U$ is the amount of consumptive water use $(\mathrm{mm}), \theta 2$ is soil moisture percentage after irrigation, $\theta 1$ is soil moisture percentage before the following irrigation, $B d$ is bulk density $\left(\mathrm{g} \mathrm{cm}^{-3}\right)$ and $E R Z$ is the effective root zone. The measured soil moisture constants (\% per weight) and bulk density $\left(\mathrm{g} \mathrm{cm}^{-3}\right)$ for the depth of $0-60 \mathrm{~cm}$ are shown in Table 1.

Table 1: Soil moisture constants of the experimental field at Giza Agricultural Station.

\begin{tabular}{ccccc}
\hline Depth & Field capacity & Wilting point & Available water & Bulk density \\
\hline $\mathrm{Cm}$ & $\%(\mathrm{~W} / \mathrm{W})$ & $\%(\mathrm{~W} / \mathrm{W})$ & $\mathrm{mm}$ & $\mathrm{G} \mathrm{cm}^{-3}$ \\
$0-15$ & 41.9 & 18.6 & 41.94 & 1.2 \\
$15-30$ & 33.7 & 17.5 & 29.16 & 1.2 \\
$30-45$ & 28.4 & 16.9 & 20.7 & 1.2 \\
$45-60$ & 28.1 & 16.5 & 22.62 & 1.3 \\
\hline
\end{tabular}

Maximum leaf area index at maximum vegetative growth was measured for both crops. Degree days from planting to anthesis and physiological maturity were calculated. At harvesting time harvest index grain and biological yield of the two crops were measured and. Consumptive water use of water for both crops was determined.

Wheat

Three wheat varieties were planted, Sids 1, Sakha 93 and Giza 168, in a randomized complete block design with three replicates. Wheat was planted on the 15 and 17 November in the first and second growing seasons, respectively. Nitrogen fertilizer in the form of urea $\left(180 \mathrm{~kg} \mathrm{ha}^{-1}, 46 \% \mathrm{~N}\right)$

Fayoum J. Agric. Res. \& Dev., Vol. 26, No.2, July, 2012 
Foad. A. Khalil, et al.,

was applied in the equaldoses (at the $1^{\text {st }}$ and $2^{\text {nd }}$ irrigations). Phosphorus fertilizer was applied in the form of single super phosphate (36 kg ha-1, 15\% $\mathrm{P}_{2} \mathrm{O}_{5}$ ) and was incorporated into the soil during field preparation. Potassium in the form of potassium sulfate $\left(57 \mathrm{~kg} \mathrm{ha}^{-1}, 48 \% \mathrm{~K}_{2} \mathrm{O}\right)$ was applied at booting stage. Second irrigation was applied $21 \mathrm{~d}$ after planting then irrigation was applied every $21-23 \mathrm{~d}$ with a total of six irrigations. Harvest was done in the $3^{\text {rd }}$ week of April in both growing seasons.

\section{Maize}

Two maize hybrids (TWC 310 and TWC 324) were planted in a randomized complete block design with three replicates. Sowing was done on the 19 and 21 June in the $1^{\text {st }}$ and $2^{\text {nd }}$ growing season, respectively. Nitrogen fertilizer in the form of urea $\left(288 \mathrm{~kg} \mathrm{ha}^{-1}, 46 \% \mathrm{~N}\right)$ was applied before the $1^{\text {st }}$ and 2 irrigation. Phosphorus fertilizer was applied in the form of single super phosphate $\left(47 \mathrm{~kg} \mathrm{ha}^{-1}, 15.5 \% \mathrm{P}_{2} \mathrm{O}_{5}\right)$ and was incorporated into the soil during land preparation. Potassium sulfate was applied before planting (120 $\mathrm{kg} \mathrm{ha}-1,48 \% \mathrm{~K}_{2} \mathrm{O}$ ). The second irrigation was applied around $21 \mathrm{~d}$ after planting, then irrigation was applied every 14-15 $\mathrm{d}$ in both growing seasons with a total of seven irrigations. Harvest was done in the second week of October in both growing seasons.

\section{CropSyst Model}

CropSyst (Cropping Systems Simulation Model) is a multi-year, multicrop, daily time step crop growth simulation model, developed with emphasis on a friendly user interface, and with a link to GIS (Geographic Information System) software and a weather generator (Stockle et al., 1994). The model's objective is to serve as an analytical tool to study the effect of cropping systems management on crop productivity and the environment. For this purpose, CropSyst simulates the soil water budget, soil-plant $\mathrm{N}$ budget, crop phenology, crop canopy and root growth, biomass production, crop yield, residue production and decomposition, soil erosion by water, and pesticide fate. These parameters are affected by weather, soil and crop characteristics, and cropping system management options. Cropping system management includes crop rotation, variety selection, irrigation, $\mathrm{N}$ fertilization, pesticide applications, soil and irrigation water salinity, tillage operations, and residue management.

\section{CropSyst model calibration and validation}

In order to assess the impact of climate change on wheat and maize, CropSyst model was calibrated and validated using the collected field data for each crop separately. Then the model was run using the developed climate change scenarios. For each crop and after each growing season, input files required by CropSyst model for Giza location and wheat and maize crops were prepared and use to run the model. Maximum leaf area index (LAI), degree dayto (maximum vegetative growth) and physiological maturity, and harvest index were used to calibrate the model for each crop. A few varietyspecific parameters were also calibrated within a reasonable range of fluctuation sets in CropSyst manual. These variety-specific parameters were: aboveground biomass-transpiration coefficient and light to above ground biomass conversion. After calibration, the model was validated using the measured data of yield and consumptive water use for the two crops. To test the goodness of fit between the measured and predicted data, percent difference between measured and predicted values for each variety in each

Fayoum J. Agric. Res. \& Dev., Vol. 26, No.2, July, 2012 
growing season were calculated, in addition to root mean squared error (Jamieson et al., 1998) and Willmott index of agreement (Willmott, 1981).

Climate change scenarios

In this work, the HadCM3 which is a coupled atmosphere- ocean general circulation model (AOGCM) developed at the Hadley Centre for Climate Prediction and Research (United Kingdom) was used (Gordon et al., 2000; Pope et al., 2000) and considered as significantly and more sophisticated than earlier versions (Hulme and Jenkins 1998). This model has a spatial resolution of $2.50 \times 3.75$ (latitude by longitude). HadCM3 provide information about climate change over the entire world during the $21^{\mathrm{st}}$ century and present information about three times slices: 2020s, 2050s, and 2080s. In order to provide information on possible changes in the world climate, the climate change models are forced to consider future scenarios. The IPCC (Nakicenovic et al., 2000) has developed emission scenarios known as Special Report on Emission Scenarios (SRES). The four SRES scenarios combined two sets of divergent tendencies: one set varying between strong economic values and strong environmental values, the other set between increasing globalization and increasing regionalization (IPCCTGCIA, 1999). Two climate change scenarios were considered in this study: A2 and B2. These selected two scenarios consider a rise in global mean temperature by 3.09 and $2.16{ }^{\circ} \mathrm{C}$, respectively, $\mathrm{CO} 2$ concentration will be 834 and 601 ppm, respectively and global mean sea level will rise by 62 and $52 \mathrm{~cm}$, respectively. As the resolution of the model is too big, using simple interpolation techniques of these percentages have been applied to fit the station site. Data were downloaded in GRIB format (Gridded Binary, is an international, public, binary format for the efficient storage of meteorological/ oceanographic variables) from the Intergovernmental Panel on Climate Change (IPCC) Data Distribution Centre Web site. The GRBCONV program was used to convert the data files from GRIB format to the more conventional ASCII (American Standard Code for Information Interchange). The download site does not offer the option to subset the data based on an area of interest, so a custom program was used to extract the data for the region of interest. HadCM3 model (Hadley Centre for Climate Prediction and Research, UK) variables were monthly precipitation, solar radiation, minimum and maximum temperatures $\mathrm{A} 2$ and $\mathrm{B} 2$ climate change scenarios were used to run the CropSyst model to predict wheat and maize yield and consumptive water use in the year of 2038s. The reason for choosing that year was to perceive how the productivity of each crop on a farm level will be affected after $30 \mathrm{yr}$. The effect of each climate change scenario on the 1 and the $2^{\text {nd }}$ season will be discussed separately as if each case could be a representation of the growing season of the year 2038s. The simplest method of downscaling is to interpolate the change fields to the site or region of interest by using Cartesian geometry and geostatistics.

\section{Adaptation strategies}

Three adaptation strategies were considered for each crop: early sowing, changing irrigation schedule and the effect of the interaction between early sowing and changing irrigation schedule. Under the new irrigation schedule, the model was adjusted to supply enough water to fill root zone area with available plant water whenever each single irrigation, was applied. This adjustment guaranteed that the growing plants will not experience water stress but heat stress under the proposed

Fayoum J. Agric. Res. \& Dev., Vol. 26, No.2, July, 2012 
climate change scenarios. The effect of these adaptation strategies on the yield of the two crops and on the required irrigation amount was compared with respect to percent of yield improvement, percent increase in irrigation water and crop water productivity. Efficient adaptation strategy is the one that increase percent of yield improvement, reduce percent increase in irrigation water and increase crop water productivity under the tested climate change scenarios.

Wheat

The effect of sowing wheat 3 wk earlier, on 21 October instead of 15 November was proposed. Changing the original irrigation schedule was done by simulating the effect of irrigation in a constant interval every $21 \mathrm{~d}$ on wheat yield, which resulted in applying a total of eight irrigations.

\section{Maize}

Early sowing by $3 \mathrm{wk}$ was also proposed for maize as an adaptation option. Furthermore, irrigation every $14 \mathrm{~d}$ with a total of seven irrigations was also proposed instead of the original irrigation schedule.

\section{RESULTS AND DISCUSSION}

\section{CropSyst model calibration and validation \\ 1. Wheat}

Results show that CropSyst model predicted wheat yield with high degree of accuracy (Table 2). Percent difference between measured and predicted wheat yield was less than $1 \%$. Root mean squared error (RMSE) was $0.0157 \mathrm{t} \mathrm{ha}^{-1}$ and Willmott index of agreement was 0.99. Singh et al. (2008) indicated that CropSyst model is more appropriate than CERES-Wheat in predicting growth and yield of wheat under different $\mathrm{N}$ and irrigation application situations, where RMSE was $0.36 \mathrm{t} \mathrm{ha}^{-1}$ compared with 0.63 $\mathrm{t} \mathrm{ha}^{-1}$ for CERES-Wheat. Whereas, Lobell and Ortiz- Monasterio (2006) stated that CERES-Wheat model was able to predict wheat yield for different imigation trials quite well with a RMSE of $0.23 \mathrm{t} \mathrm{ha}^{-1}$. Regarding to consumptive water use, the model prediction was highly accurate too. Percent difference between measured and predicted wheat consumptive water use was less than 1\%. RMSE was $0.5692 \mathrm{~mm}$ and Willmott index of agreement was 0.9999 (Table 2). Similar results were obtained by Wang et al. (2006), where RMSE was $0.07 \mathrm{~mm}$ for evapotranspiration and Pannkuk et al. (1998), where it was $0.05 \mathrm{~mm}$ when CropSyst was used to predict evapotranspiration.

Table 2. Measured versus predicted wheat yield and consumptive use in the two growing seasons.

\begin{tabular}{|c|c|c|c|c|c|c|c|}
\hline \multirow{3}{*}{$\begin{array}{c}\begin{array}{c}\text { Growing } \\
\text { season } \\
2007 / 08\end{array} \\
\end{array}$} & \multirow{2}{*}{ Variety } & \multicolumn{2}{|c|}{ Wheat yield $\left(\mathrm{t} \mathrm{ha}^{-1}\right)$} & \multicolumn{3}{|c|}{$\begin{array}{c}\text { Consumptive water } \\
\text { use (mm) }\end{array}$} & \multirow{2}{*}{ PD\% } \\
\hline & & Measured & Predicted & & Measured & Predicted & \\
\hline & Sids 1 & 5.92 & 5.91 & 0.20 & 380.95 & 379.80 & 0.30 \\
\hline & Sakha 93 & 5.86 & 5.82 & 0.64 & 362.86 & 361.88 & 0.72 \\
\hline & Giza 168 & 5.52 & 5.51 & 0.16 & 358.10 & 355.64 & 0.69 \\
\hline \multirow[t]{3}{*}{ 2008/09 } & Sids 1 & 5.40 & 5.39 & 0.19 & 400.95 & 400.82 & 0.03 \\
\hline & Sakha 93 & 5.93 & 5.36 & 0.61 & 366.90 & 366.09 & 0.22 \\
\hline & Giza 168 & 5.38 & 5.38 & 0 & 367.41 & 365.64 & 0.41 \\
\hline RMSE & & 0.0157 & & & 0.5692 & & \\
\hline W1 & & 0.9999 & & & 0.9999 & & \\
\hline
\end{tabular}

Fayoum J. Agric. Res. \& Dev., Vol. 26, No.2, July, 2012 


\section{Maize}

CropSyst model predicted maize yield and consumptive water use with high degree of accuracy. Percentage of difference between measuredand predicted values was less than $1 \%$ for both yield and consumptive water use. Willmott index of agreement was the highest and RMSE was very low (Table 3). Díaz-Ambrona et al. (2004) stated that the simulations of maize yield by CropSyst were close to measured values, where RMSE was $1.2 \mathrm{t} \mathrm{ha}^{-1}$. These results are in agreement with what was found by Rivington et al. (2007), Moriondo et al. (2007) and Tingem et al. (2007), where they stated that CropSyst is recognized by its robustness and relatively easy applicability with commonly available information. The accurate results obtained from running the model for the two crops under both growing seasons implied that the model can be used in simulating wheat and maize yield under any other situation. Although the above situation provides only a limited evaluation of the model, the model should be further tested as more data from more treatments in different locations and years become available. However, for the purposes of this study we are confident in that the model worked sufficiently well to warrant the exploration of the effect of climate change on wheat and maize yield and water requirements.

Effect of climate change scenarios on yield and consumptive water use

Excessive losses in both wheat and maize yield could occur under both climate change scenarios and high increase in consumptive water use would be expected too in the year of 2038s (Table 4). These yield losses could be as high as 47 and 54\% for wheat and maize, respectively. Consumptive water use could be elevated by 7.14 and $19.95 \%$ for wheat and maize, respectively.

Table 3. Measured versus predicted maize yield and consumptive water use in the two growing seasons.

\begin{tabular}{|c|c|c|c|c|c|c|c|}
\hline $\begin{array}{l}\text { Growing } \\
\text { season }\end{array}$ & Hybrid & \multicolumn{2}{|c|}{ Maize yield $\mathbf{t} \mathbf{h a}^{-1}$} & PD\% & $\begin{array}{r}\text { Consum } \\
\text { us } \\
\text { Measurec }\end{array}$ & $\begin{array}{l}\text { ive water } \\
\text { mm } \\
\text { predicted }\end{array}$ & PD\% \\
\hline 2008 & TWC 310 & 5.71 & 5.7 & 0.17 & 545.70 & 542.82 & 0.53 \\
\hline & TWC 324 & 5.41 & 5.42 & 0.18 & 531.00 & 530.59 & 0.08 \\
\hline 2009 & TWC 310 & 5.92 & 5.89 & 0.51 & 540.60 & 539.14 & 0.27 \\
\hline & TWC 324 & 5.79 & 5.78 & 0.17 & 525.00 & 524.02 & 0.19 \\
\hline RMSE & & 0.0087 & & & 0.0092 & & \\
\hline W1 & & 0.9999 & & & 0.9999 & & \\
\hline
\end{tabular}

PD\%: percent difference between measured and predicted values; RMSE: root mean squared error; WI: Willmott index of agreement.

Furthermore, wheat var. Sakha 93 (V2) and maize hybrid TWC324 (V2) were found to be more tolerant to heat stress, compared with the rest of the varieties. That tolerance was expressed in lower yield reduction values under both climate change scenarios (Table 4). Similar trend was observed for both crops in the second season, where the lowest yield reduction could occur for wheat var. Sakha 93 and maize hybrid TWC324 as a result of being more tolerant to heat stress (Table

Fayoum J. Agric. Res. \& Dev., Vol. 26, No.2, July, 2012 
5). Therefore, the analysis will focus on these two varieties. Furthermore, the results also showed that, under both climate change scenarios, wheat yield reduction was lower in the second seasons for the three varieties, compared with the first season (Tables 4 and 5). However, the situation was different for maize, where higher yield reduction could exist in the second season, compared with the first one (Tables 4 and 5).

Table 4. Percent change in yield and consumptive water use of wheat and maize under climate change scenarios in the first season.

\begin{tabular}{|c|c|c|c|c|c|c|c|c|c|}
\hline \multirow{2}{*}{ Variety } & \multirow{2}{*}{$\begin{array}{c}\text { Climate } \\
\text { scenario }\end{array}$} & $\begin{array}{c}\text { Yield } \\
\mathrm{t} \mathrm{ha}^{-1}\end{array}$ & $\begin{array}{c}\text { PR } \\
\%\end{array}$ & CU mm & PI $\%$ & $\begin{array}{c}\text { Yield } \\
\mathrm{tha}^{-1}\end{array}$ & $\begin{array}{c}\text { PR } \\
\%\end{array}$ & $\begin{array}{c}\text { CU } \\
\mathrm{mm}\end{array}$ & PI \% \\
\hline V1 & Current & 5.91 & $\mathrm{NP}$ & 379.80 & $\mathrm{NP}$ & 5.70 & $\mathrm{NP}$ & 542.82 & $\mathrm{NP}$ \\
\hline & $\mathrm{A} 2$ & 3.20 & 46 & 398.94 & 5 & 2.61 & 54 & 605.75 & 12 \\
\hline & $\mathrm{B} 2$ & 3.61 & 39 & 402.81 & 6 & 3.35 & 41 & 651.13 & 20 \\
\hline V2 & Current & 5.82 & $\mathrm{NP}$ & 361.88 & $\mathrm{NP}$ & 5.42 & $\mathrm{NP}$ & 530.42 & $\mathrm{NP}$ \\
\hline & $\mathrm{A} 2$ & 3.22 & 45 & 386.31 & 7 & 2.55 & 53 & 597.90 & 13 \\
\hline & $\mathrm{B} 2$ & 3.63 & 38 & 387.71 & 7 & 3.27 & 40 & 625.94 & 18 \\
\hline V3 & Current & 5.51 & $\mathrm{NP}$ & 355.64 & $\mathrm{NP}$ & $\mathrm{NP}$ & $\mathrm{NP}$ & $\mathrm{NP}$ & $\mathrm{NP}$ \\
\hline & A2 & 2.90 & 47 & 375.65 & 6 & $\mathrm{NP}$ & $\mathrm{NP}$ & $\mathrm{NP}$ & $\mathrm{NP}$ \\
\hline & $\mathrm{B} 2$ & 3.32 & 40 & 375.80 & 6 & $\mathrm{NP}$ & $\mathrm{NP}$ & $\mathrm{NP}$ & $\mathrm{NP}$ \\
\hline
\end{tabular}

V1: wheat var. Sids 1 or maize hybrid TWC310; V2: wheat var. Sakha 93 or maize hybrid TWC324; V3: wheat var. Giza 168; PR\%: percent reduction between measured and predicted yield; NP: not applicable; CU: consumptive water use; PI\%: percent increase between measured and predicted consumptive water use; A2 and B2: two climate change scenarios.

Table 5. Percent change in yield and consumptive water use of wheat and maize under climate change scenarios in the second season.

\begin{tabular}{|c|c|c|c|c|c|c|c|c|c|}
\hline \multirow[b]{2}{*}{ Variety } & \multirow{2}{*}{$\begin{array}{l}\text { Climate } \\
\text { scenario }\end{array}$} & \multicolumn{4}{|c|}{ Wheat } & \multicolumn{4}{|c|}{ Maize } \\
\hline & & $\begin{array}{c}\text { Yield } \\
\left(\mathrm{t} \mathrm{ha}^{-1}\right)\end{array}$ & PR \% & $\begin{array}{c}\mathrm{CU} \\
(\mathrm{mm})\end{array}$ & PI \% & $\begin{array}{l}\text { Yield } \\
\left(\mathrm{t} \mathrm{h} \mathrm{h}^{-1}\right)\end{array}$ & PR \% & $\begin{array}{c}\mathrm{CU} \\
(\mathrm{mm})\end{array}$ & PI $\%$ \\
\hline \multirow[t]{3}{*}{ V1 } & Current & 5.39 & NP & 400.82 & NP & 5.89 & NP & 539.14 & NP \\
\hline & A2 & 3.42 & 37 & 420.25 & 5 & 2.57 & 56 & 616.03 & 14 \\
\hline & B2 & 3.45 & 36 & 427.45 & 7 & 2.98 & 50 & 620.01 & 15 \\
\hline \multirow[t]{3}{*}{ V2 } & Current & 5.36 & NP & 366.09 & $\mathrm{NP}$ & 5.78 & NP & 524.02 & NP \\
\hline & A2 & 3.41 & 36 & 388.22 & 6 & 2.63 & 55 & 597.90 & 14 \\
\hline & B2 & 3.47 & 35 & 389.05 & 6 & 3.04 & 47 & 580.48 & 11 \\
\hline \multirow[t]{3}{*}{ V3 } & Current & 5.38 & $\mathrm{NP}$ & 365.64 & NP & NP & NP & NP & NP \\
\hline & $\mathrm{A} 2$ & 3.40 & 37 & 386.77 & 6 & NP & $\mathrm{NP}$ & $\mathrm{NP}$ & $\mathrm{NP}$ \\
\hline & B2 & 3.47 & 36 & 386.88 & 6 & $\mathrm{NP}$ & NP & $\mathrm{NP}$ & $\mathrm{NP}$ \\
\hline
\end{tabular}

V1: wheat var. Sids 1 or maize hybrid TWC310; V2: wheat var. Sakha 93 or maize hybrid TWC324; V3: wheat var. Giza 168; PR\%: percent reduction between measured and predicted yield; NP: not applicable; CU: consumptive water use; PI\%: percent increase between measured and predicted consumptive water use; A2 and B2: two climate change scenarios.

Fayoum J. Agric. Res. \& Dev., Vol. 26, No.2, July, 2012 
IRRIGATION SCHEDULING TO INCREASE WATER UNIT

Effect of adaptation strategies on crop water productivity

Regarding to wheat planted in both seasons under A2 climate change scenario, the proposed adaptation strategies did not improved water productivity, however it could save irrigation water and it increase yield losses under either early sowing or early sowing and irrigation every $21 \mathrm{~d}$ (Table 6). Early sowing and irrigation every $21 \mathrm{~d}$ could save 3 and $1 \%$ of the applied irrigation water and reduced yield by 7 and $1 \%$ in the first and second seasons, respectively (Table 6). Regarding to maize grown under the same respective climate change scenario, irrigation every $14 \mathrm{~d}$ increased water productivity in both seasons, with 3 and $1 \%$ increase in applied irrigation water in both seasons, respectively, which reflected on yield improvement by 4.24 and $3.63 \%$ in both seasons, respectively (Table 6).

Table 6. Percentage of change in yield and irrigation amounts for wheat and maize and corresponded water productivity values in both seasons under A2 scenario.

\begin{tabular}{|c|c|c|c|c|c|c|}
\hline \multirow[b]{2}{*}{ Adaptation strategy } & \multicolumn{3}{|c|}{ Wheat (Sakha 93) } & \multicolumn{3}{|c|}{ Maize (TWC 324) } \\
\hline & $\begin{array}{c}\text { Change } \\
\text { in yield } \\
\%\end{array}$ & $\begin{array}{c}\text { Change in } \\
\text { irrigation } \\
\%\end{array}$ & $\begin{array}{c}\text { WP Kg } \\
\mathrm{m}^{-3}\end{array}$ & $\begin{array}{c}\text { Change } \\
\text { in yield } \\
\%\end{array}$ & $\begin{array}{l}\text { Change in } \\
\text { irrigation \% }\end{array}$ & $\begin{array}{c}\text { WP Kg } \\
\mathrm{m}^{-3}\end{array}$ \\
\hline $2007 / 2008$ & NP & NP & 0.75 & NP & NP & 0.32 \\
\hline ES & -10 & -5 & 0.66 & -9 & +12 & 0.25 \\
\hline $\mathrm{I}$ & 0 & +11 & 0.69 & +4 & +3 & 0.38 \\
\hline ES x I & -7 & -3 & 0.69 & 0 & +8 & 0.33 \\
\hline $2008 / 2009$ & NP & NP & 0.80 & NP & NP & 0.43 \\
\hline ES & -5 & -0.59 & 0.75 & +2.42 & +7 & 0.43 \\
\hline $\mathrm{I}$ & +2 & +12.35 & 0.74 & +3.63 & +1 & 0.46 \\
\hline ES x I & -1 & -1.19 & 0.80 & +1.56 & +2 & 0.44 \\
\hline
\end{tabular}

ES: sowing either wheat or maize 3 wk earlier; I: irrigation every 21 or $14 \mathrm{~d}$ for wheat or maize, respectively; NP: not applicable; ES x I: interaction between early sowing and irrigation; WP: water productivity.

The situation was different for wheat under B2 climate change scenario, where water productivity was increased under sowing wheat $3 \mathrm{wk}$ earlier and irrigation was applied every $21 \mathrm{~d}$ in both seasons (Table 7). Under this scenario, both yield improvement and irrigation water saving could occur. Results in Table 7 indicated that wheat yield could improve by $2 \%$ under saving $3 \%$ of the irrigation water in the first season. Whereas, in the second season, $8 \%$ improvement in wheat yield could happen with less than $1 \%$ increase in the applied irrigation water. Applying irrigation every $14 \mathrm{~d}$ for maize would be the appropriate adaptation option to be used to reduce yield losses and to increase water productivity under both seasons, especially in the second season, where maize yield was improved by $9 \%$, with $1 \%$ increased in the applied irrigation water (Table 7). Shifts in yield and yield stability largely depend on assumptions about future emissions, the climate projections, and the downscaling procedure used to generate the climatic data at the regional scale typically required as input to crop models. Olesen et al. (2007) noted that for a site-based analysis the method used for downscaling is more crucial than the choice of a specific climate scenario. They also pointed out that the use of climate model outputs directly as

Fayoum J. Agric. Res. \& Dev., Vol. 26, No.2, July, 2012 
input to crop simulation model is appropriate. Thus, our results showed that the downscaling process of HadCM3 model was appropriate to Egypt as it was shown by the statistical analysis.

The results of the field experiments showed the climatic condition under which wheat grown was more stressful in the first growing season, compared with the second; expressed in lower yield in the second growing season (Table 2 ). That effect was also pronounced under both climate change scenarios, where wheat yield reduction was lower on in the second growing season (Table 4 and 5). The situation was reversed for maize yield, where it was higher in the second growing (Table 3 ) and yield reduction was higher in the second growing season under climate change conditions (Table 4 and 5). This result implied that CropSyst model was very successful in conveying the state of the growing wheat and maize plants as it affected by the prevailing climatic conditions during each growing season, which reflected on the simulated yield under current climate and under climate change scenarios.

Regional assessments of the effects of climate change on crop production are needed at various decision levels, and they are necessary to quantify the economic impacts at the farm and regional scale. Our results implied that small farmers could be the segment of the population whose livelihoods are most susceptible to the impacts of climate variability, because of the high yield reduction in wheat-maize rotation. Under A2 climate change scenario, wheat yield is expected to be reduced by an average of $41 \%$ and maize yield could be reduced by an average of $56 \%$ in the year of 2038s. But, wheat and maize yield could be reduced by an average of 36 and $45 \%$, respectively under B2 climate change scenario in the same respective year. Thus, the possible increase in climate variability could be recognized as one of the most critical issues that could be devastating to the economy, especially under increasing the gap between wheat and maize production and its consumption as a result of population increase in Egypt.

Egyptian farmers' irrigation practices are aimed at maximizing crop production through excessive use of irrigation water, which result in large water losses. As the problem of water scarcity commenced, improving the productivity of existing water resources is an important aspect to produce more food for the increasing population, especially under climate change conditions. Therefore, the adaptation strategy to be use to relief the harm effect of climate change on the growing crops should be easy to implement, with no additional economical costs, which was the case in our research. For wheat, the best adaptation strategy was early sowing and changing irrigation schedule. Under this situation, a certain amount of irrigation water could be saved and use in irrigating new lands to contribute in increasing wheat production under climate change conditions. The best outcome from using adaptation strategy for wheat could occur under B2 climate change scenario in the second growing season (less stressful climate change scenario and better growing conditions). Thus, wheat yield could be improved by $8 \%$ with an increase in the applied irrigation water by only $1 \%$ (Table 7 ).

Fayoum J. Agric. Res. \& Dev., Vol. 26, No.2, July, 2012 
IRRIGATION SCHEDULING TOINCREASE WATER UNIT.

Table 7. Percent change in yield and irrigation amounts for wheat and maize and corresponded water productivity values in both seasons under B2 scenario.

\begin{tabular}{|c|c|c|c|c|c|c|}
\hline \multirow[b]{2}{*}{$\begin{array}{l}\text { Adaptation } \\
\text { strategy }\end{array}$} & \multicolumn{3}{|c|}{ Wheat (Sakha 93) } & \multicolumn{3}{|c|}{ Maize (TWC 324) } \\
\hline & $\begin{array}{c}\text { Change in } \\
\text { yield } \%\end{array}$ & $\begin{array}{c}\text { Change in } \\
\text { irrigation } \\
\%\end{array}$ & $\begin{array}{c}\text { WP Kg } \\
\mathrm{m}^{-3}\end{array}$ & $\begin{array}{c}\text { Change } \\
\text { in yield } \\
\%\end{array}$ & $\begin{array}{l}\text { Change in } \\
\text { irrigation \% }\end{array}$ & $\begin{array}{c}\text { WP } \\
\mathrm{Kg} \mathrm{m}^{-3}\end{array}$ \\
\hline $2007 / 2008$ & NP & NP & 0.85 & NP & NP & 0.45 \\
\hline ES & -8 & +10 & 0.68 & +1 & +15 & 0.43 \\
\hline $\mathrm{I}$ & 0 & +1 & 0.86 & +1 & +2 & 0.48 \\
\hline ES x I & +2 & -3 & 0.91 & -4 & +6 & 0.43 \\
\hline $2008 / 2009$ & $\mathrm{NP}$ & $\mathrm{NP}$ & 0.79 & NP & $\mathrm{NP}$ & 0.43 \\
\hline ES & -3 & -1 & 0.77 & +9 & +10 & 0.43 \\
\hline I & -1 & +15 & 0.69 & +9 & +1 & 0.52 \\
\hline ES x I & +8 & +1 & 0.92 & +8 & +6 & 0.48 \\
\hline
\end{tabular}

ES: sowing either wheat or maize 3 wk earlier; I: irrigation every 21 or $14 \mathrm{~d}$ for wheat or maize, respectively; NP: not applicable; ES x I: interaction between early sowing and irrigation; WP: water productivity.

Changing irrigation schedule was also an effective adaptation option for maize, where yield improvement could occur under climate change condition. Although the second growing season was more stressful for the growing maize plants, maize yield was positively responded to irrigation rescheduling as an adaptation option under B2 climate change scenario. Maize yield was improved by $8 \%$ with $2 \%$ increase in irrigation water (Table 7). Gardner et al. (1985) stated that maize is characterized by having high water use efficiency as a result of high photosynthesis and growth rate under high light and temperature. That explain why maize yield positively responded to low percent increase in the applied irrigation water under climate change scenarios.

\section{CONCLUSIONS}

Sustainable land and water management combined with innovative agricultural technologies could mitigate climate change and help poor farmers adapt to its impacts. New knowledge, technology and policy for agriculture have never been more critical, and adaptation and mitigation strategies must urgently be applied to national and regional development programs. Without these measures developing countries will suffer increased food insecurity. The real challenge under climate change conditions is to use adaptation strategies, which should improved agricultural management practices to reduce the damage of climate change on the yield of the growing crops, and in the mean time conserve a certain percentage of applied irrigation water. Finally, technological advances in production, including crop improvements through breeding or planting varieties with higher water use efficiency could reduce yield losses to a minimal.

Fayoum J. Agric. Res. \& Dev., Vol. 26, No.2, July, 2012 
Allen, R.G., L.S. Pereira, D. Raes, and M. Smith. 1998. Crop evapotranspiration. Guidelines for computing crop water requirements. FAO irrigation and Drainage Paper No 56. FAO, Rome, Italy.

Ashraf, M., M.M. Saeed and M.N. Asghar. 2002. Evaporation pan: A tool for irrigation scheduling. Journal of Drainage and Water Management 6:45-51.

Bagga, A.K., and I.M. Rawson. 1977. Contracting responses of morphologically similar wheat varieties to temperature appropriate to warm temperature climates with hot summers: A study in controlled environment. Australian Journal of Agricultural Research 40:965-980.

Cheikh, N., and R.J. Jones. 1994. Disruption of maize kernel growth and development by heat stress: The role of cytokinin/abscisic acid balance. Plant Physiology 166:45-51.

Díaz-Ambrona, C.G.H., R.G. Pazos, and C.O.M. Tovar. 2004. Global climate change and food security for small farmers in Honduras. $4^{\text {th }}$ International Crop Science Congress, Australia. 26 September-1 October. Aust. Soc. of Agron., Brisbane, Queensland, Australia.

Eid, H.M., N.G. Ainer, M.A. Rady, and W.M. Rizk. 1993. Impact of climate change on simulated wheat yield and water needs. p. 309-312. Proceeding of the First Egyptian Hungarian Conference on Environment, Saint Catherine, Sinai, Egypt. April 5-7.

Eid, H.M., N.G. Ainer, K.M.R. Yousef, M.A.M. Ibrahim, and G.M. Gad El-Rab. 1992. Climate change crop modeling study on wheat. p. 113-130. $5^{\text {th }}$ Egypt Botanical Conference, Saint Catherine, Sinai, Egypt.

Eid, H.M., N.A. Anton and A.M. Tarrad. 1994. Comparative study on Egyptian wheat varieties and their response to high temperatures. Annals of Agricultural Science Moshtohor (Egypt) 32:143-154.

Eid, H.M, S.M. El-Marsafawy, N.G. Ainer, N.M. El- Mowelhi and O. El-Kholi. 1997. Vulnerability and adaptation to climate change in maize crop. Meteorology \& Environmental Cases Conference, Cairo, Egypt. 2-6 March. Authority of Meteorology, Cairo, Egypt.

Eid, H.M., and N.M. El-Mowelhi. 1998. Impact of climate change on field crops and water needs in Egypt. African International Environmental Conference, Egypt. October 1998.

FAO. 1996. Irrigation scheduling from theory to practice. Water Reports 8.384 p. FAO, Rome, Italy.

FAO. 2003. Unlocking the water potential of agriculture. FAO Corporate Document Repository. 260 p. FAO, Rome, Italy.

Friend, D.J.C. 1965. Ear length and spikelet number of wheat grown at different temperatures and light intensities. Canadian Journal of Botany 43:343-353.

Gardner, F.P., R.B Pearce, and R.L. Mitchell. 1985. Physiology of crop plants. Iowa State University Press, Ames, Iowa, USA.

Gordon, C., C. Cooper, C.A. Senior, H. Banks, J.M. Gregory, T.C. Johns, et al. 2000. The simulation of sea surface temperature, sea ice extents and ocean heat transports in a version of the Hadley Centre coupled model without flux adjustments. Climate Dynamics 16:147-168.

Hulme, M., and G.J. Jenkins. 1998. Climate change scenarios for the UK: Scientific Report. UKCIP Technical Report $N^{\circ}$ 1. Climate Research Unit, Norwich, UK.

Israelsen, O.W., and V.E. Hansen. 1962. Irrigation principles and practices. p. 55123. John Wiley \& Sons, New York, USA.

Fayoum J. Agric. Res. \& Dev., Vol. 26, No.2, July, 2012 
IPCC-TGCIA. 1999. Guidelines on the use of scenario data for climate impact and adaptation assessment. Version 1. 69 p. Prepared by Carter, T.R., Hulme M., and Lal. M. Intergovernmental Panel on Climate Change (IPCC), task Group on Scenarios for Climate Impact Assessment. Available at http://ipcc-ddc.cru. uea.ac.uk/guidelines/guidance.pdf (accessed June 2009).

Jamieson, P.D., J.R. Porter, J. Goudriaan, J.T. Ritchie, H. van Keulen, and W. Stol. 1998. A comparison of the models AFRCWHEAT2, CERES-Wheat, Sirius, SUCROS2 and SWHEAT with measurements from wheat grown under drought. Field Crops Research 55:23-44.

Jensen, M.E. 1980. Design and operation of farm irrigation systems. Monograph 3. p. 220-256. American Society of Agricultural Engineering, Michigan, Michigan, USA.

Jones, P.G., and P.K. Thornton. 2003. The potential impacts of climate change on maize production in Africa and Latin America in 2055. Global Environmental Change 13:51-59.

Khalil, F.A. 1996. Scheduling irrigation for faba bean using evaporation pan method. M.Sc. College of Agriculture. Zagazig University, Moshtohorcity, Egypt.

Khalil, F.A.F., A.M. Tammam, I.A. Amin, and K.A. Mohamed. 2006. Scheduling irrigation for some wheat cultivars under Upper Egypt conditions. Mansoura University Journal of Agricultural Sciences 31:561-572.

Kolderup, I. 1979. Application of different temperatures in three growth phases of wheat. II. Effects on ear size and seed setting. Acta Agriculturae Scandinavica 29:11-116.

Lobell, D.B., and J.I. Ortiz-Monasterio. 2006. Evaluating strategies for improved water use in spring wheat with CERES. Agricultural Water Management 84:249-258.

McMaster, G.S. 1997. Phenology, development, and growth of wheat (Triticum aestivum L.) shoot apex: A review. Advances in Agronomy 59:63-118.

Monjardino, P., A.G. Smith, and R.J. Jones. 2005. Heat stress effects on protein accumulation of maize endosperm. Crop Science 45:1203-1210.

Moriondo, M., F. Maselli, and M. Bindi. 2007. A simple model of regional wheat yield based on NDVI data. European Journal of Agronomy 26:266-274.

Nakicenovic, N., J. Alcamo, G. Davis, B. de Vries, J. Fenhann, S. Gaffin, et al. 2000. Intergovernmental Panel on Climate Change (IPCC) special report on emission scenarios. 599 p. Cambridge University Press, Cambridge, UK.

Olesen, J.E., T.R. Carter, C.H. Díaz-Ambrona, S. Fronzek, T. Heidmann, T. Hickler, et al. 2007. Uncertainties in projected impacts of climate change on European agriculture and terrestrial ecosystems based on scenarios from regional climate models. Climatic Change 81:123-143.

Pannkuk, C.D., C.O. Stockle and R.I. Papendick. 1998. Evaluating CropSyst simulations of wheat management in a wheat-fallow region of the US Pacific Northwest. Agricultural Systems 57:121-133.

Pope, V.D., M.L. Gallani, P.R. Rowntree, and R.A. Stratton.2000. The impact of new physical parameterization in the Hadley Centre Climate Model-HadCM3. Climate Dynamics 16:123-146.

Ritchie, S.W., J.J. Hanway, and G.O. Benson. 1993. How corn plant develops. Iowa State Univ. Sci. Tech. Cooperative Ext. Services. Report No 48. 20 p. Iowa State University, Ames, Iowa, USA.

Fayoum J. Agric. Res. \& Dev., Vol. 26, No.2, July, 2012 
Rivington, M., K.B. Matthews, G. Bellocchi, K. Buchan, C.O. Stöckle, and M. Donatelli. 2007. An integrated assessment approach to conduct analyses of climate change impacts on whole-farm systems. Environmental Modelling \& Software 22:202-210.

Rosenzweig, C., and D. Hillel. 1998. Climate change and the global harvest. Oxford University Press, New York, USA.

Saini, H.S., and D. Aspinall. 1982. Sterility in wheat (Triticum aestivum L.) induced by water stress or high temperature: Possible mediation by abscisic acid. Australian Journal of Plant Physiology 9:529-537.

Shaw, R.H. 1983. Estimates of yield reductions in corn caused by water and temperature stress. p. 49-66. In Ruper, C.D. Jr., P.J. Kramer (eds.) Crop relations to water and temperature stress in humid temperate climates. Westview Press, Boulder, Colorado, USA.

Singh, A.K., R. Tripathy, and U.K Chopra. 2008. Evaluation of CERES-Wheat and CropSyst models for water-nitrogen interactions in wheat crop. Agricultural Water Management 95: 776-786.

Sofield, I.L., T. Evans, and I.F. Wardlaw. 1977. The effect of temperature and light on grain filling in wheat. Royal Society of New Zealand Bulletin 12:909-915.

Stockle, C.O., S. Martin and G.S. Campbell. 1994. CropSyst, a cropping systems model: water/nitrogen budgets and crop yield. Agricultural Systems 46:335359.

Tingem, M., M. Rivington, S.N.A. Ali, and J.J. Colls. 2007. Assessment of the ClimGen stochastic weather generator at Cameroon sites. African Journal of Environmental Science and Technology 1:86-92.

Torriani, D., P. Calanca, M. Lips, H. Ammann, M. Beniston, and J. Fuhrer. 2007b. Regional assessment of climate change impacts on maize productivity and associated production risk in Switzerland. Regional Environmental Change 16:23-29.

Torriani, D.S., P. Calanca, S. Schmid, M. Beniston, and J. Fuhrer. 2007a. Potential effects of changes in mean climate and climate variability on the yield of winter and spring crops in Switzerland. Climate Research 34:59-69.

Tubiello, F.N., M. Donatelli, C. Rosenzweig, and C.O. Stockle. 2000. Effects of climate change and elevated $\mathrm{CO} 2$ on cropping systems: model predictions at two Italian sites. European Journal of Agronomy 13:179- 189.

Wang, Z., B. Zhang, L. Xiao-yan, K. Song, D. Liu, and S. Zhang. 2006. Using CropSyst to simulate spring wheat growth in Black Soil Zone of Northeast China. Pedosphere 16:121-134.

Willmott, C.J. 1981. On the validation of models. Physical Geography 2:184-194.

Wrigley, C. 2006. Global warming and wheat quality. CFW 51:34-36. doi: 10.1094/CFW-51-0034.

Fayoum J. Agric. Res. \& Dev., Vol. 26, No.2, July, 2012 
جدولة الرى لزيادة انتاجية وحدة المياة لدورة محصول القمح والذرة الثامية

$$
\text { تحت ظروف التغير في المناخ }
$$

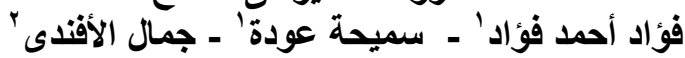

1 قسم بحوث المقتنات المائية والرى الحقلى ـ معهد بحوث الأراضى والمياه والبيئة ـ مركز البحوث

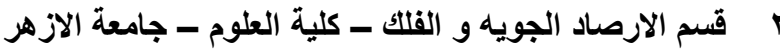

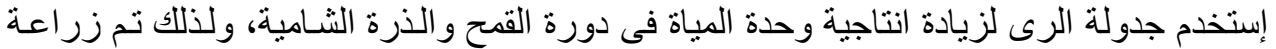

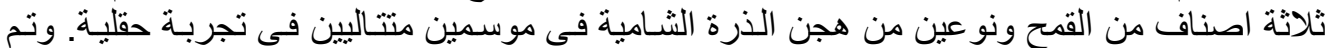

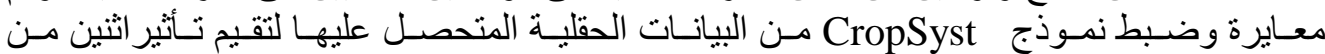

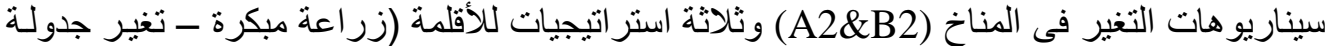

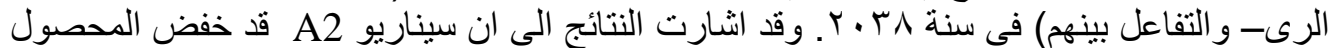

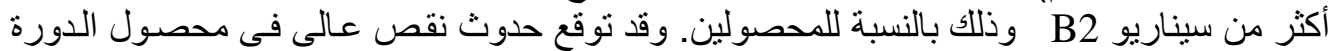

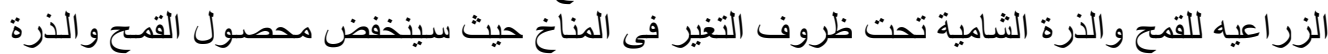

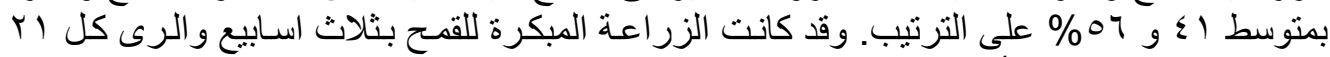

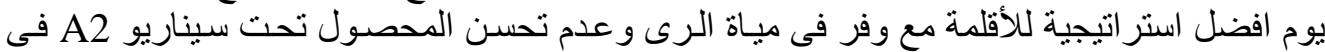

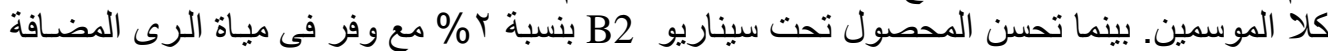

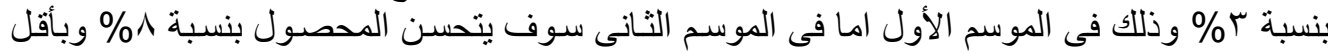

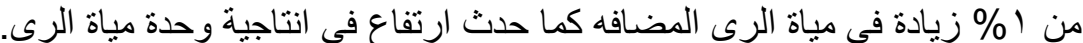

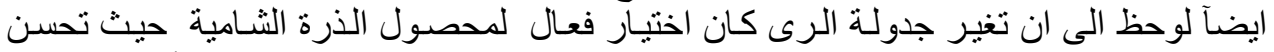

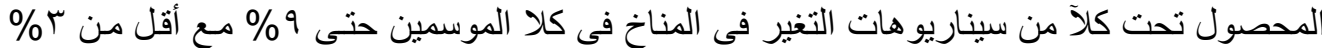
زيادة فى مياة الرى المضافة ونحسن انتاجية فى انتاجية وحدة مياة الرى الرى الرئ

Fayoum J. Agric. Res. \& Dev., Vol. 26, No.2, July, 2012 